\title{
Effects of flooding and shading on growth and gas exchange of Vochysia divergens Pohl (Vochysiaceae) of invasive species in the Brazilian Pantanal
}

\section{Ândrea Carla Dalmolin*, Higo José Dalmagro', Francisco de Almeida Lobo², Mario Zortéa Antunes Junior ${ }^{3}$, Carmen Eugenia Rogríguez Ortíz ${ }^{4}$, George Louis Vourlitis ${ }^{5}$}

\author{
${ }^{1}$ Programa de Pós-Graduação em Física Ambiental, Instituto de Física, Universidade Federal de Mato Grosso, \\ Cuiabá, MS, Brazil. \\ 2Departamento de Solos e Engenharia Rural, Faculdade de Agronomia e Medicina Veterinária, Universidade \\ Federal de Mato Grosso, Cuiabá, MS, Brazil. \\ 3Programa de Pós-Graduação em Agricultura Tropical, Faculdade de Agronomia e Medicina Veterinária, \\ Universidade Federal de Mato Grosso, Cuiabá, MS, Brazil. \\ ${ }^{4}$ Departamento de Botânica e Ecologia, Instituto de Biociência, Universidade Federal de Mato Grosso, Cuiabá, \\ MS, Brazil. \\ ${ }^{5}$ Department of Biological Sciences, California State University, San Marcos, CA, USA.
}

${ }^{\star}$ Corresponding author: andreacarlad@gmail.com

Received: 18 April 2012; Accepted: 04 August 2012

\begin{abstract}
Vochysia divergens Pohl (commonly known as cambara) is a pioneer tree species that is native to the Amazon Basin but has been invading the seasonally flooded wetlands of the Brazilian Pantanal, forming monospecific communities. The physiological aspects associated with cambara invasion, including the effects of flooding and shading on growth and leaf gas exchange, are unknown but may shed light on why cambara is able to invade this novel habitat so rapidly. Thus, we conducted a manipulative experiment to quantify the effects of shading and flooding on the growth, gas exchange and leaf nutrient content of $V$. divergens saplings. Based on previous research we hypothesized that (1) experimental flooding would have no effect on the growth and gas exchange of $V$. divergens, and (2) experimental shading would reduce the growth and gas exchange of $V$. divergens regardless of the water treatment plants are subjected. Our data indicate that shading significantly increased the height, stomatal conductance $\left(g_{s}\right)$, and transpiration $(T)$ of $V$. divergens saplings, especially for plants exposed to normal irrigation. Experimental flooding significantly reduced rates of leaf production, plant height, and gas exchange; however, shaded plants exposed to flooding had a higher water use efficiency than plants exposed to full sun and flooding, because $T$ was more depressed than net photosynthesis $(A)$ in flooded plants exposed to full sun. Despite the inhibitory effects of flooding and shading, $V$. divergens saplings exhibited positive growth and $C$ gain, regardless of the growth light environment or water level, indicating that the growth and leaf gas exchange of species is tolerant to both flooding and shading. Such tolerance to a wide variety of hydrological and growth light conditions presumably explains the ability of cambara to invade, and ultimately form dense, monospecific stands in the Brazilian Pantanal.
\end{abstract}

Keywords: cambara; physiological stress, photosynthesis, plant ecophysiology, stomatal conductance, tropical wetlands. 


\section{INTRODUCTION}

Invasive species colonize a new area via accidental or intentional introduction and thrive, fundamentally altering native plant and animal species abundance, biodiversity, and ecosystem processes, such as carbon (C) and nutrient cycling and storage (Bossard et al., 2000; Vourlitis et al., 2011). Invasion into these novel habitats is often influenced by disturbances such as fire and/or grazing (Lake and Lieshman, 2004) or by events such as interannual variation in seasonal flooding (Nunes da Cunha and Junk, 2004). While it is difficult to determine which species will become invasive, species with invasive potential often share a wide range of traits including high reproductive output, vegetative reproduction, high relative and population growth rates, early reproductive age, and high resource use efficiency (Rejmanek and Richardson, 1996; Funk, 2008; Osunkoya et al., 2010). In particular, traits associated with maximizing $C$ gain, such as high leaf area production, maximum photosynthesis, and specific leaf area (projected leaf area/leaf dry mass), appear to be positively correlated with invasive performance (Funk, 2008). Expression of these traits may be highly dependent on resource availability (Sala et al., 1996; Siemann and Rogers, 2007) and/or developmental stage (Ward et al., 2006); however, invasive species often exhibit high phenotypic and physiological plasticity (Funk, 2008), which allows them to expand their distribution across spatially heterogenous landscapes.

Physiological and/or phenotypic plasticity is of crucial importance for the survival of plant species that invade areas with substantially different resource availability. For example, plants invading areas subject to periodic flooding are exposed to extended periods of hypoxia and/or anoxia (Armstrong et al., 1994; Maurenza et al., 2009) and high concentrations of toxic products (McKee and McKevlin, 1993; Jackson and Colmer, 2005), and successful invaders must be able to tolerate widely fluctuating hydrological conditions. In contrast, riparian species invading drier upland areas must be able to tolerate periodic drought, and many successful invaders exhibit flexibility in root system morphology, which is critical for exploiting ephemeral and/or deep water reserves (Sala et al., 1996; Lite and Stromberg, 2005).

The invasion of Vochysia divergens Pohl (commonly known as cambara) in the wetlands of the Brazilian Pantanal is a well-documented example of a species that has rapidly colonized large areas, forming dense, monospecific stands known as cambarazais (Pott and Pott, 1994; Silva et al., 2000; Nunes da Cunha and Junk, 2004; Ariera and
Nunes da Cunha, 2006; Junk et al., 2006). V. divergens is a woody, evergreen, and light-demanding pioneer species that is native to the Amazon Basin (Pott and Pott, 1994; Lorenzi, 1998). V. divergens first arrived in the Pantanal in the 1970s (Nunes da Cunha and Junk, 2004), and aerial surveys conducted in 2000 revealed that over $3 \%$ of the Pantanal is now covered by monospecific $V$. divergens forests (Silva et al., 2000). The reason for the invasion is still poorly understood; however, interactions between inundation, soil physical properties, and fire appear to be critical for invasion success (Nunes da Cunha and Junk, 2004). Once established, $V$. divergens has been shown to significantly alter soil chemical properties such as nutrient concentration, cation exchange capacity, and soil organic matter content (Vourlitis et al., 2011).

Some researchers attribute the expansion of $V$. divergens in the Pantanal to rapid growth under intense light, tolerance to flooding, and the production of numerous water-dispersed seeds (Nunes da Cunha and Junk, 2004; Ariera and Nunes da Cunha, 2006). However, most studies on $V$. divergens deal with population and community dynamics (Junk and Nunes da Cunha, 2005; Ariera and Nunes da Cunha, 2006; Junk et al., 2006; Santos et al., 2006; Nunes da Cunha et al., 2007), and the physiological aspects of $V$. divergens invasion are largely unknown. For example, the expansion of $V$. divergens is most rapid in highlight, grassland-dominated areas (Nunes da Cunha and Junk, 2004), but seedlings and saplings are often subjected to shading by canopy trees and/or bunch grasses during recruitment. Coupled with prolonged seasonal flooding, which can cause mortality in flood-sensitive tree species (Larcher, 1995) and a decline in the growth and gas exchange of flood-adapted tree species (Fernández et al., 1999; Mielke et al., 2003; Maurenza et al., 2009; Herrera et al., 2010; Oliveira and Joly, 2010), V. divergens seedlings and saplings are likely subjected to physiological stress as they invade these novel habitats.

Based on the fact that $V$. divergens is considered a light-demanding pioneer species (Lorenzi, 1998), and the fact that this species is adapted to seasonal flooding in its native (Amazonian forest), we hypothesized that (1) flooding would have no effect on the growth and gas exchange of $V$. divergens, and (2) experimental shading would reduce the growth and gas exchange of $V$. divergens regardless of the water treatment plants are subjected. To quantify the effects of shading and flooding on the growth, gas exchange and leaf nutrient content of young $V$. divergens plants we conducted a manipulative experiment in wich we simulated canopy shading and the seasonal flood regime. 


\section{MATERIAL AND METHODS}

Plant material and experimental setup: One year old $V$. divergens trees (saplings) that were approximately $0.5 \mathrm{~m}$ tall and $\mathrm{a} \leq 0.3 \mathrm{~m}$ trunk diameter were harvested from the Pantanal in an area that $V$. divergens was invading ( $\mathrm{n}=60$ trees). Harvested saplings were returned to a shade house and transferred into $8 \mathrm{~L}$ plastic pots containing nutrient-rich native soil. Plants were allowed to recover for 3 months under natural understory shade, which was similar to the environmental that they were growing in prior to harvest, until they showed good health (production of new green leaves).

After the recovery phase, surviving plants (28 out of the initial 60) were randomly allocated to one of four treatment groups ( $n=7$ plants per treatment group):

1. flooded plants exposed to full-sunlight (floodedunshaded);

2. flooded plants exposed to simulated understory shade (flooded-shaded);

3. non-flooded plants exposed to full-sunlight (unfloodedunshaded);

4. non-flooded plants exposed to simulated understory shade (unflooded-shaded).

Simulated flooding was accomplished by placing each $8 \mathrm{~L}$ pot into a larger $10 \mathrm{~L}$ pot that was filled with water so that the water level was maintained $0.04 \mathrm{~m}$ above the soil. The non-flooded plants were manually irrigated every two days with approximately two liters of water, which was enough water to keep the soil moist but not saturated. Water was added to both treatments every two days to avoid large variations in water level (flooded) or soil moisture (unflooded). To simulate understory shade, pots were placed in a shade house covered with shade cloth, which attenuated approximately $78 \%$ of the ambient light. Spectrophotometric analysis indicated that the shade cloth transmitted wavelengths $>600 \mathrm{~nm}$, which are similar to those transmitted by a typical plant canopy (Holmes and Smith, 1977). Plants exposed to full sun were placed outside the shade house. Treatments were initiated on day of the year (DOY) 246 and continued until DOY 311, corresponding to a 65 day experimental period.

Measurements of photosynthetic active radiation (PAR) were performed inside and outside the shadehouse using quantum sensors (LI-190SB, LI-COR,
Lincoln, NE, USA). Air temperature was also measured within and outside the shadehouse using type-T (copperconstantan) thermocouples, while relative humidity was measured outside the shadehouse using a shielded thermistor and relative humidity sensor (HMP-35, Vaisala, Inc., Helsinki, Finland). Data were stored as hourly averages on a datalogger (CR 1000, Campbell Scientific, Inc., Logan, UT, USA).

Growth analysis and gas exchange: To evaluate tree growth, height and leaf number were recorded twice before (DOY 217 and 230) and three times after the initiation of the treatments (DOY 277, 294 and 311). During each measurement, all leaves on each plant were counted and the height of the main trunk was measured from the soil surface to the apex of the plant.

Gas exchange measurements were initiated the day after the treatments started (DOY 247) and 19 measurements were carried out over the 65 day experiment. Rates of stomatal conductance to water vapour $\left(g_{s}\right)$, net photosynthesis $(A)$, and transpiration $(E)$, and intercellular concentration of $\mathrm{CO}_{2}\left(C_{\mathrm{i}}\right)$ were measured using a portable photosynthesis system (LI-6400, LI-COR Bioscience, Lincoln, NE, USA). The system was adjusted to provide a photosynthetically active radiation (PAR) of $1,000 \mu \mathrm{mol} \mathrm{m} \mathrm{m}^{-2} \mathrm{~s}^{-1}$, block temperature of $28^{\circ} \mathrm{C}$, relative humidity of $50-60 \%$, and an ambient concentration of $\mathrm{CO}_{2}\left(C_{\mathrm{a}}\right)$ of $400 \mu \mathrm{mol} \mathrm{mol}{ }^{-1}$. These temperature, humidity, and $C_{\text {a }}$ values were chosen to provide optimal conditions for leaf gas exchange, while the PAR of $1,000 \mu \mathrm{mol} \mathrm{m}^{-2} \mathrm{~s}^{-1}$ ensures light saturating PAR for both shaded and unshaded leaves (Miranda et al. 2005). Measurements were started after a period of approximately seven min, to allow the control system of the photosynthesis system and the leaf to adjust to the measurement conditions. Gas exchange was measured using the fourth or fifth leaf from the apex that was fully expanded and had no obvious disease symptoms such as chlorosis $(n=1$ leaf per plant). All measurements were performed between $0700 \mathrm{~h}$ to $1200 \mathrm{~h}$, local time, and plants within all treatments were measured each hour to ensure that diurnal variations in temperature and/or humidity would affect each treatment combination equally. Leaf gas exchange and the $C_{i}$ were calculated using the LI-6400 system software and the instantaneous water use efficiency (WUE) was calculated as the ratio between $A$ and $E$.

Foliar macronutrients: Analysis of leaf macronutrients was done on DOY 307 when plants had many leaves and harvesting leaves would presumably not detrimentally affect plant physiological performance. Four leaves per 
plant were harvested, washed in distilled water, placed in an oven at $60^{\circ} \mathrm{C}$ for 72 hours, and ground in Willey type mill (Miyazawa et al., 2009). $\mathrm{Ca}^{2+}$ and $\mathrm{Mg}^{2+}$ concentration was determined by atomic absorption spectrophotometry (AA1475, Varian, Inc., Palo Alto, CA USA) after nitropercloric digestion (Borges et al., 2005). P was determined by colorimetric analysis using the vitamin $\mathrm{C}$ method (Braga and DeFelipe, 1974). $\mathrm{K}^{+}$concentration was determined by flame atomic emission spectrometry (DM-61, Digimed, São Paulo, Brazil) following Isaac and Kerber (1971). Total N was determined using the micro-Kjedahl method (Golterman et al., 1978).

Statistical analysis: The rate of leaf production and plant growth (height) was estimated using linear regression, and while non-linear models may be more appropriate for assessing plant growth characteristics (Hunt and Parsons, 1974), linear models performed as well or better than non-linear models to characterize the change in leaf production and plant height over time. Differences in growth rate, calculated as the slope of the linear trend, were assessed using two-way ANOVA with water level and growth light condition as fixed effects. A repeated-measures ANOVA was used to assess treatment effects on leaf gas exchange with water level and growth light condition as fixed effects, and a twoway ANOVA was used to assess the effects of water level and light on leaf macronutrient concentration.

\section{RESULTS}

Microclimate: There as a significant difference in mean $\left( \pm\right.$ SD) PAR inside $\left(570 \pm 14 \mu \mathrm{mol} \mathrm{m}^{-2} \mathrm{~s}^{-1}\right)$ and outside $\left(125 \pm 7 \mu \mathrm{mol} \mathrm{m} \mathrm{m}^{-2} \mathrm{~s}^{-1}\right)$ the shadehouse (Figure $1 \mathrm{~A})$. The average $( \pm \mathrm{SD})$ temperature inside the shadehouse $\left(35.8 \pm 0.8^{\circ} \mathrm{C}\right)$ was not statistically different from the mean temperature outside the shadehouse $\left(36.1 \pm 0.76^{\circ} \mathrm{C}\right)$, and the highest average temperature for both environments was observed at $1400 \mathrm{~h}$, local time (Figure $1 \mathrm{~B})$. The mean $( \pm \mathrm{SD})$ relative humidity outside the shadehouse was $55.2 \pm 1.5 \%$, and was highest in the early morning hours and lowest during the mid-afternoon hours when temperature was at a diurnal maximum (Figure 1B).

Plant growth and leaf production: All plants exposed to shading and flooding survived the 65th day of the experimental period, although many plants exhibited leaf chlorosis. We did not observe the development of hypertrophic lenticels or adventitious roots over the course of the experiment.

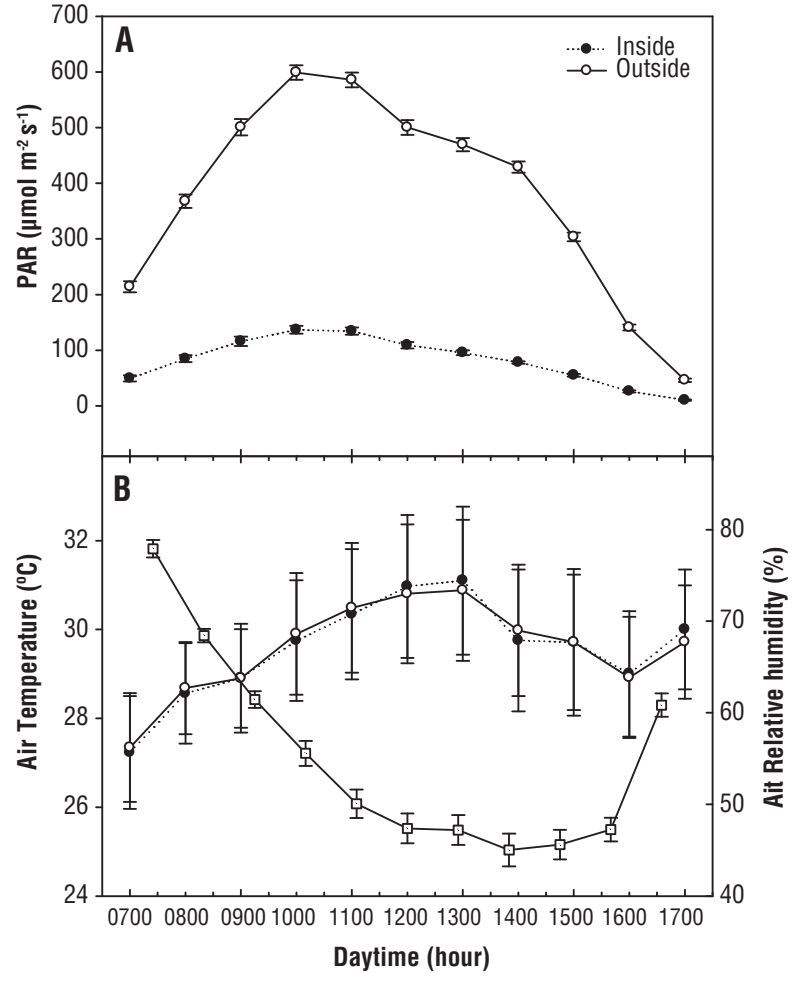

Figure 1. (A) Photosynthetic active radiation (PAR $\mu \mathrm{mol} \mathrm{m} \mathrm{m}^{-2} \mathrm{~s}^{-1}$ ) and $(B)$ air temperature and relative humidity inside (closed symbols, dashed lines) and outside (open symbols, solid lines) the shadehouse. Mean $( \pm S E ; n=61$ days $)$.

Leaf production declined significantly for plants exposed to flooding but not shading (Figure 2A). The mean $( \pm 95 \%$ confidence interval $-\mathrm{Cl}$ ) rate of leaf production of non-flooded plants exposed to full-sun and shade was $0.36 \pm 0.14$ leaves day ${ }^{-1}$ and $0.47 \pm 0.15$ leaves day, respectively. In contrast, plants exposed to flooded conditions produced on average 0.03 (full-sunlight) and 0.06 (shaded) leaves day ${ }^{-1}$, indicating that flooded plants produced few leaves over the 61st day of experiment (Figure 2A).

Variations in water table and shading significantly affected plant height and there was a significant water table (W) and light (L) interaction (Figure 2B). Plants exposed to the shade and normal irrigation treatment had the highest mean $( \pm 95 \% \mathrm{Cl})$ growth rate $\left(0.040 \pm 0.007 \mathrm{~m}\right.$ day $\left.^{-1}\right)$ followed by plants exposed to full sun and normal irrigation $\left(0.017 \pm 0.005 \mathrm{~m}\right.$ day $\left.^{-1}\right)$. In general, plants exposed to shading had a higher growth rate than plants exposed to full-sunlight in their respective water table treatments (Figure 2B). 


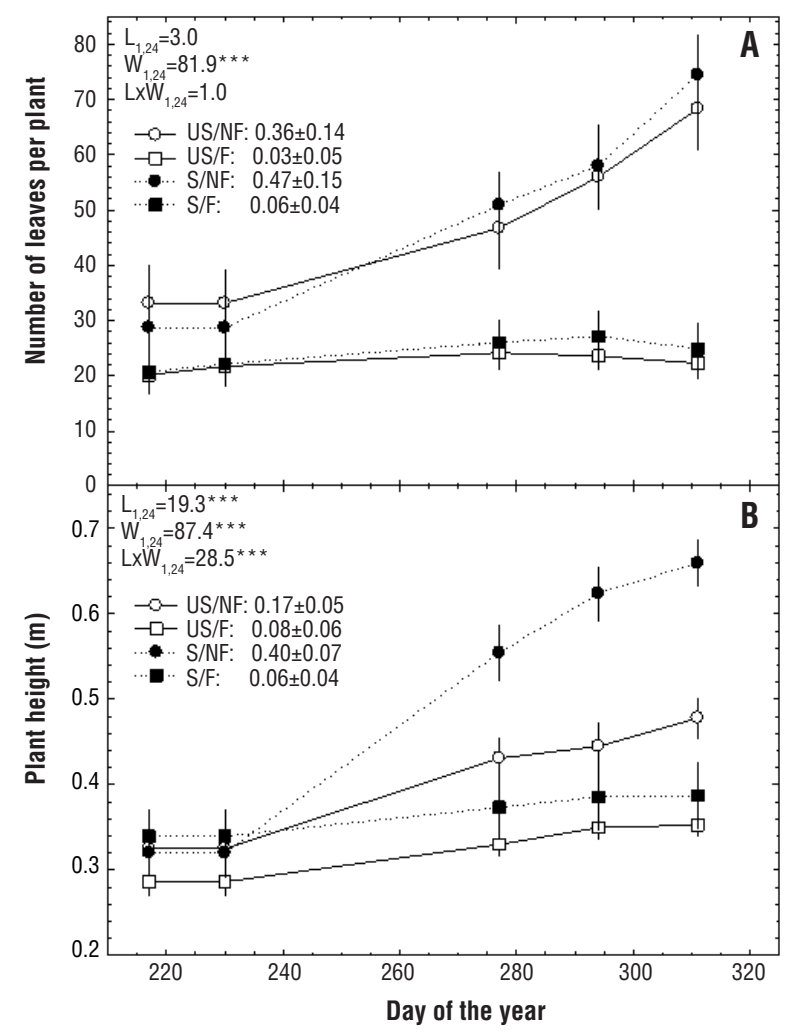

Figure 2. The mean $( \pm S E ; n=7$ plants per treatment combination) number of leaves per plant $(A)$ and plant height (B) for Vochysia divergens saplings exposed to unshaded (open symbols, solid lines) or shaded (closed symbols, dashed lines) and flooded (squares) or non-flooded (circles) conditions. The mean $( \pm 95 \%$ confidence interval) rates of leaf production $(A)$ and plant growth $(B)$ for each light (shaded (S) and unshaded (US)) and water table (flooded (F) and non-flooded (NF)) treatment combination are shown with the figure legends. The results of a 2-way ANOVA (F-statistics, degrees of freedom) for the rate of leaf production $(A)$ and plant growth (B) as a function of water table depth (W), light $(L)$ and the $\mathrm{LxW}$ interaction are also shown. ${ }^{* * *}(\mathrm{p}<0.001)$.

Gas exchange and leaf macronutrient concentration: Shading did not affect rates of net photosynthesis $(A)$ but flooding rapidly and significantly reduced $A$ after the treatment was initiated (Figure $3 A$ ). Day-to-day variations in $A$ were large regardless of treatment group and there did not appear to be a discernable temporal trend in $A$. When averaged over the experimental period, mean $( \pm 95 \% \mathrm{Cl})$ $A$ was $3.0 \pm 0.5$ and $3.5 \pm 0.4 \mu \mathrm{mol} \mathrm{m}{ }^{-2} \mathrm{~s}^{-1}$ for flooded trees exposed to shading and full-sun, respectively, which was $30 \%$ of the $A$ of plants exposed to normal irrigation (Figure 3A).
Rates of transpiration $(T)$ and stomatal conductance $\left(g_{s}\right)$ were significantly affected by flooding and shading, with the highest $T$ and $g_{\mathrm{s}}$ observed for plants exposed to shading and normal irrigation (Figure 3B). When averaged over the study period, significant shading and flooding effects on $g_{s}$ were apparent and there was a significant LxW interaction (Figure 4B). This interaction was caused by a significantly higher $g_{\mathrm{s}}$ for plants exposed to shading and normal irrigation $\left(0.27 \pm 0.07 \mathrm{~mol} \mathrm{~m}^{-2} \mathrm{~s}^{-1}\right)$ compared to plants exposed to fullsunlight and normal irrigation $\left(0.15 \pm 0.04 \mathrm{~mol} \mathrm{~m}^{-2} \mathrm{~s}^{-1}\right)$.

The ratio of internal to external $\mathrm{CO}_{2}$ concentration $\left(C_{\mathrm{i}}: C_{\mathrm{a}}\right)$ was significantly affected by flooding but not shading; however, there was a significant $L X W$ interaction (Figure $3 C$ ). Temporal variations in the $C_{:}: C_{\text {a }}$ were relatively larger for shaded plants; however, the significant LxW interaction occurred because plants exposed to shading and normal irrigation had the highest $C_{\mathrm{i}}: C_{\mathrm{a}}(0.65-0.8)$ while plants exposed to shading and flooding had the lowest (0.45-0.6; Figure 3C). When averaged over the experimental period, the effect of flooding on the $C_{i}: C_{a}$ was again dependent on light level (Figure $4 C$ ), but only plants exposed to shade and normal irrigation had a $C_{\mathrm{i}}: C_{\mathrm{a}}$ that was close to the theoretical optimum ratio of 0.70 for $\mathrm{C}_{3}$ plants (Wong et al., 1979).

Time series for the instantaneous WUE were similar to those observed for $C_{i}: C_{a}$ (data not shown), and there was a significant effect of water table depth and a significant $L X W$ interaction for WUE values averaged over the experimental period (Figure 4D). Shaded plants exposed to flooding had the highest WUE followed by unshaded plants exposed to normal irrigation.

Leaf macronutrient concentrations were significantly lower in flooded plants for all macronutrients except $\mathrm{N}$ (Table 1). Differences in leaf macronutrient concentration between flooded and normally irrigated plants appeared to be slightly larger in plants exposed to shaded conditions; however, the direct effects of light were not statistically significantly and there was no LxW interaction (Table 1).

\section{DISCUSSION}

Effects of flooding and shading on $V$. divergens physiological performance: We originally hypothesized that flooding would have no effect on the growth and gas exchange of $V$. divergens, but experimental shading would reduce the growth and gas exchange of $V$. divergens based on the fact that $V$. divergens is considered a light-demanding pioneer species that this species is considered to be light 


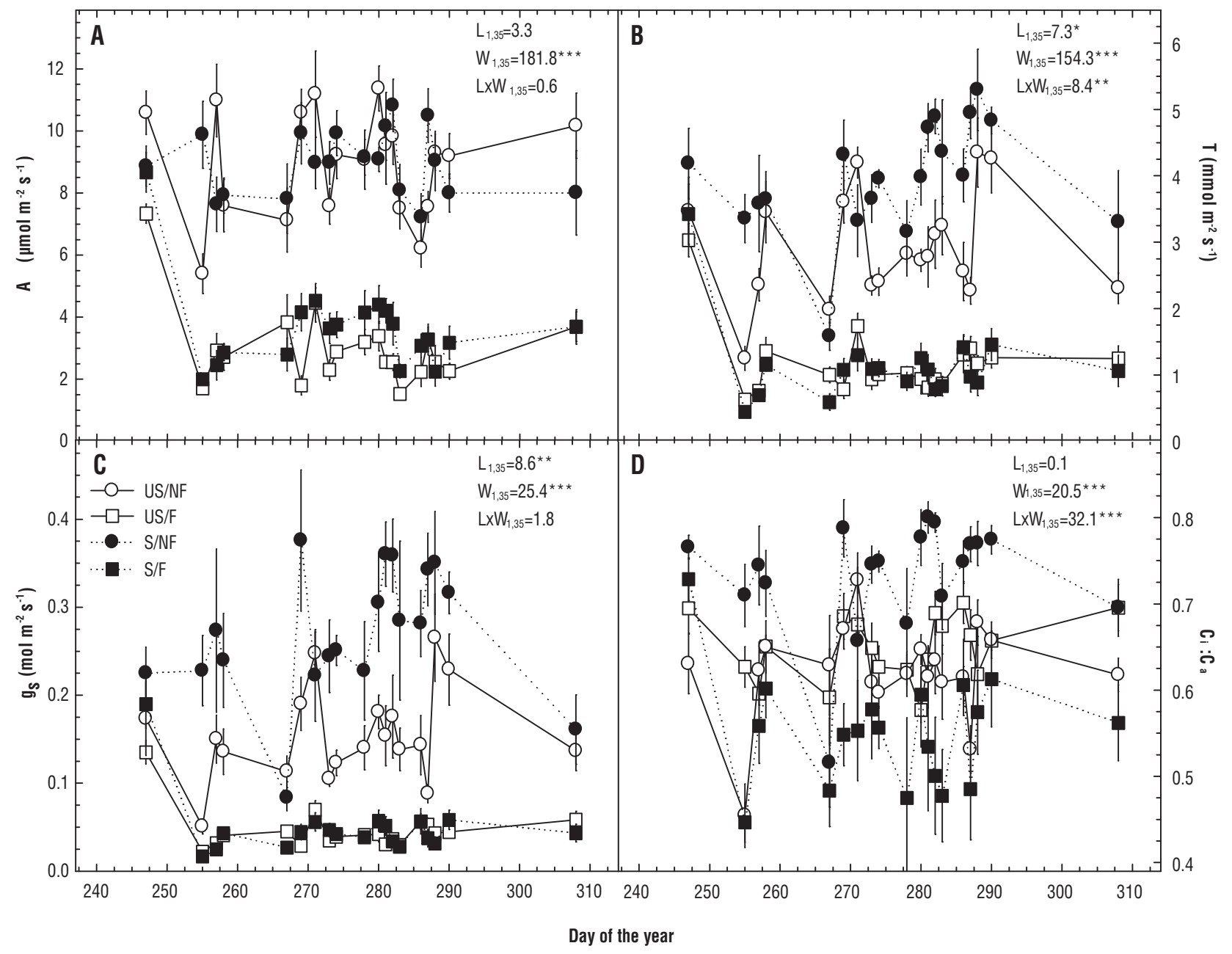

Figure 3. Time series for the rate of $(A)$ net photosynthesis, $(B)$ transpiration, $(C)$ stomatal conductance, and $(D)$ the $C_{i}: C_{a}$ ratio for Vochysia divergens saplings exposed to unshaded (open symbols, solid lines) or shaded (closed symbols, dashed lines) and flooded (squares) or non-flooded (circles) conditions. The results of repeated-measures ANOVA for water table depth (W), light (L) and the LxW interaction are also shown. Mean $\left( \pm S E ; n=7\right.$ plants per treatment combination). ${ }^{* \star}(p<0.01){ }^{* \star *}(p<0.001)$.

demanding and adapted to seasonal flooding in its native Amazonian forest (Lorenzi, 1998). However, our data suggest that flooding was more important for determining growth and leaf gas exchange, while shading was either less important or dependent on the water level the saplings were exposed to.

While flooding resulted in a decline in growth, some of the anatomical and morphological features commonly found in plants adapted to flooding, like hypertrophy of lenticels and the presence of adventitious roots (Colmer and Greenway, 2010; Shimamura et al., 2010), were not observed in $V$. divergens saplings. However, flooded $V$. divergens saplings showed reduced growth and chlorotic leaves, which is a common response to flooding (Ishida et al., 2002; Mielke et al., 2003). Plants subjected to hypoxia or anoxia exhibit a reduction in chlorophyll synthesis because of an accumulation of ethylene (Sena and Kozlowski, 1988) and/or a reduction in cytokinin synthesis (Zhang et al., 2000). Moreover, the microbial production of ethylene in anoxic soils provides an additional exogenous source to plants (Hunt et al., 1981). In turn, ethylene promotes an increase in the activity of chlorophyllase and oxidase enzymes, which are responsible for the degradation of chlorophyll (Jacomino et al., 2003). Furthermore, the reduction in foliar nutrient concentrations in flooded $V$. divergens plants implies a decline in nutrient uptake, and under anaerobic conditions ATP levels are reduced, which 


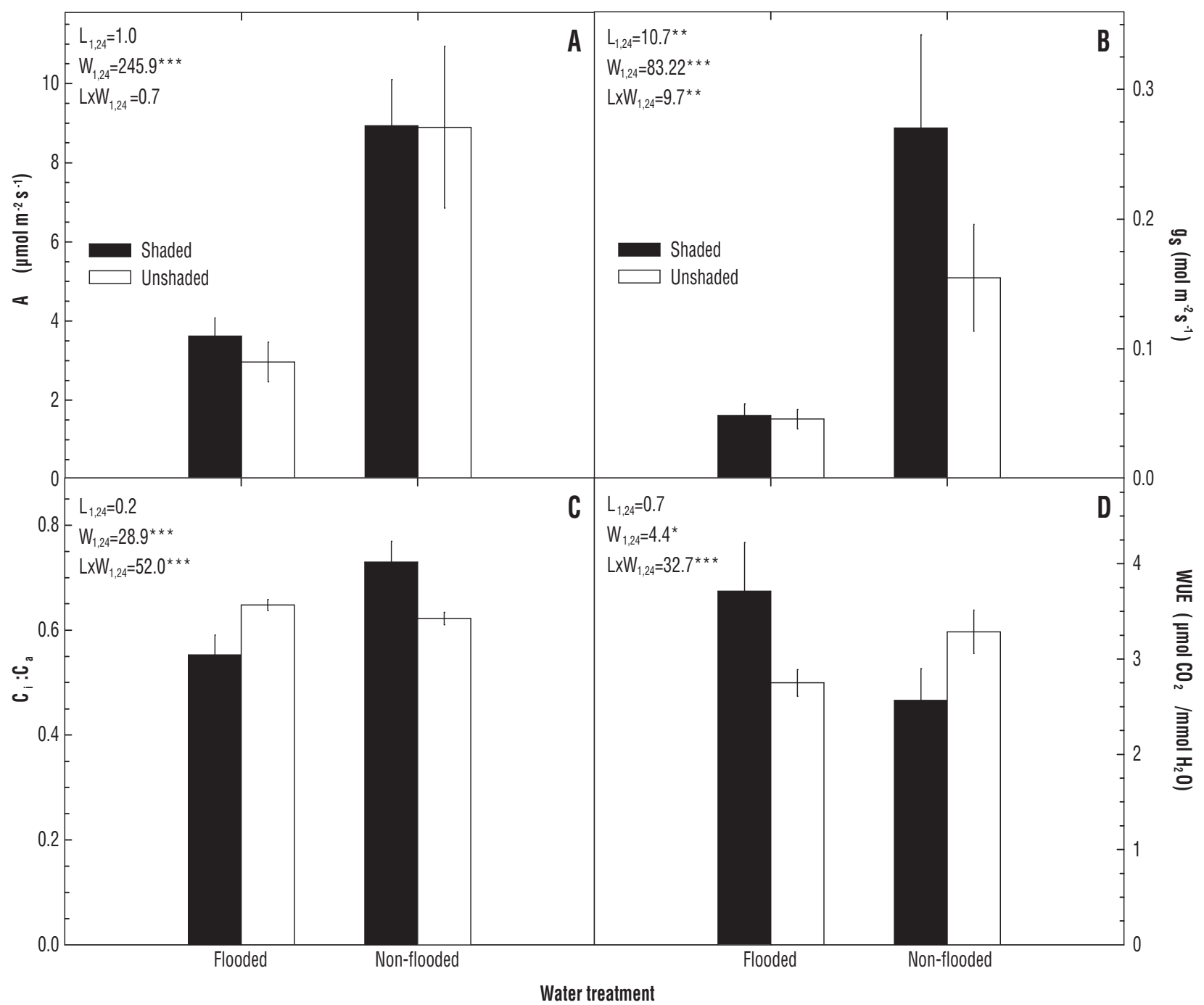

Figure 4. Net photosynthesis rate $(A)$, stomatal conductance $(B)$, the $C_{i}: C_{a}$ ratio $(C)$, and the instantaneous water use efficiency $(D)$ for Vochysia divergens saplings exposed to unshaded (open bars) or shaded (closed bars) and flooded or non-flooded conditions. The results of a 2-way ANOVA (F-statistics, degrees of freedom) for water table depth $(\mathrm{W})$, light $(\mathrm{L})$ and the $\mathrm{LxW}$ interaction are also shown. Data were averaged over the 65 th day of experimental period. Mean $( \pm 95 \%$ confidence interval; $n=7$ plants per treatment combination). ${ }^{* *}(p<0.01){ }^{* * *}(p<0.001)$.

Table 1. Mean leaf $( \pm \mathrm{SE})$ tissue nitrogen, phosphorus, potassium, calcium, and magnesium concentration $\left(\mathrm{g} \mathrm{kg}^{-1}\right)$ of Vochysia divergens saplings exposed to different water table (flooded vs. non-flooded) and light (shaded vs. full-sun) treatment combinations ( $\mathrm{n}=7 \mathrm{plants}$ per treatment combination). The results of a 2-way ANOVA (F-statistic, degrees of freedom) with light and water treatment as fixed effects are also shown.

\begin{tabular}{lccrrrrc}
\hline \multirow{2}{*}{ Element } & \multicolumn{2}{c}{ Shaded } & \multicolumn{2}{c}{ Unshaded } & \multicolumn{2}{c}{ F-statistics } \\
\cline { 2 - 7 } & Flooded & Non-flooded & Flooded & Non-flooded & Light & Water & Light $x$ water \\
\hline $\mathrm{N}$ & $8.10 \pm 0.43$ & $11.90 \pm 1.37$ & $11.20 \pm 1.06$ & $11.67 \pm 1.04$ & 1.9 & 4.1 & 2.5 \\
$\mathrm{P}$ & $0.46 \pm 0.03$ & $0.75 \pm 0.05$ & $0.51 \pm 0.03$ & $0.67 \pm 0.02$ & 0.1 & $40.5^{\star}$ & 4.0 \\
$\mathrm{~K}$ & $3.49 \pm 0.38$ & $7.03 \pm 1.00$ & $4.69 \pm 0.23$ & $6.53 \pm 0.36$ & 0.4 & $21.5^{*}$ & 2.1 \\
$\mathrm{Ca}$ & $1.89 \pm 0.21$ & $2.68 \pm 0.22$ & $2.17 \pm 0.10$ & $2.88 \pm 0.26$ & 1.3 & $12.4^{* *}$ & 0.1 \\
$\mathrm{Mg}$ & $0.81 \pm 0.09$ & $1.62 \pm 0.14$ & $1.20 \pm 0.05$ & $1.63 \pm 0.15$ & 2.9 & $27.0^{*}$ & 2.4 \\
\hline
\end{tabular}

${ }^{*} p<0.01 ;{ }^{*} p<0.001$. 
impairs the active absorption of nutrients (Ishida and Carvalho, 2002; Rehen et al., 2009). While speculative, a decline in tissue nutrient concentration may have in part explained the flood-induced decline in growth and gas exchange for the $V$. divergens saplings studied here.

While biochemical limitations to $V$. divergens physiological performance were likely important, only plants exposed to the normal irrigation and shade treatment had a $C_{\mathrm{i}}: C_{\mathrm{a}}$ similar to the optimum value of 0.7 for $\mathrm{C}_{3}$ plants (Wong et al., 1979), indicating that stomatal limitations to $A$ and plant growth were important as well. Interestingly plants exposed to normal irrigation and full-sunlight exhibited a decline in $g_{s}$ and $C_{i}: C_{a}$ compared to shaded plants, presumably because shading reduced leaf temperature and the leaf-air vapor pressure deficit, alleviating a decline in leaf water potential that would ultimately limit $g_{s}$.

Plants exposed to flooding have increased levels of abscisic acid (ABA) (Wilkinson and Davies, 2002), which causes a decline in $g_{s}$ (Holbrook et al., 2002) even without any apparent loss of turgor (Maurenza et al., 2009). Anaerobic production of ethanol and lactic acid (Crawford, 1992; Drew, 1997; Oliveira and Joly, 2010) can also lead to a reduction in xylem water potential and $g_{\mathrm{s}}$ (Pezeshki et al., 1993; Herrera et al., 2010).

The reduction in $g_{\mathrm{s}}$ can be considered a survival mechanism for plants in flood conditions (Mielke et al., 2003). Flooding reduces the hydraulic conductivity of the root because hypoxia induces root suberisation or lignification (Clark and Harris, 1981) and/or a decrease in the synthesis of aquaporins of root cell membranes (Tournaire-Roux et al., 2003). Under these conditions, regulation in the gas exchange by the stomata becomes critical for survival because water loss from transpiration cannot be balanced by water uptake. The immediate consequence of the reduction in $g_{\mathrm{s}}$ is a reduction in the availability of photoassimilates leading to a decline in growth (Bradford, 1983; Kozlowski, 1997; Kozlowski and Pallardy, 2002). For $V$. divergens saplings the growth rate was significantly positive correlated with $g_{\mathrm{s}}(\mathrm{r}=0.86$; $p<0.001)$. For many flood-sensitive species the decline in $g_{\mathrm{s}}$ to an immediate decline in $\mathrm{C}$ uptake and eventual death (Larcher, 1995); while for more flood tolerant species, declines in conductance may limit $\mathrm{C}$ uptake but positive $\mathrm{C}$ gain may protect individuals from mortality until flooding subsides (Joly and Crawford, 1982; Mielke et al., 2003).

\footnotetext{
Links between $V$. divergens physiological performance and invasion success: Our data indicate that $V$. divergens was tolerant of shading, and in some cases shading helped increase gas exchange $\left(g_{\mathrm{s}}\right)$ that
}

maximized growth. This result is consistent with Dalmolin et al. (in press), who measured $A \times$ PAR curves and found no significant differences in the PAR response for shaded and unshaded plants. In retrospect, this result is really not too surprising, regardless of whether $V$. divergens is considered pioneer species, because in the field one can observe that saplings that are below dense tree and/or grass canopies. According to Joly and Crawford (1982), $V$. divergens also appears to be flood-tolerant because it is able to accumulate biomass during flood exposure. Clearly flooding reduced growth and physiological performance in $V$. divergens saplings; however, plants exhibited rapid, highly flexible changes in growth and gas exchange in response to flooding. Such flooding and shade tolerance presumably promotes the establishment and recruitment of $V$. divergens in seasonally-flooded areas that exhibit significant variations in hydrology over a short period of time (Funk, 2008). One could envision a scenario where seeds carried by seasonal floodwaters are dispersed to new habitat, and provided germination conditions are favorable, seedlings and saplings survive, grow, and gain $C$ in flooded areas regardless of the growth light environment. As the seasonal flood waters recede, gas exchange and growth can increase rapidly, thus promoting the establishment of $V$. divergens in grass-dominated areas of the Pantanal. Clearly, this scenario is speculative and more research is needed to determine if similar patterns hold in their naturalized setting and to better explain the mechanisms of flood and shade tolerance for this species.

In conclusion, saplings of $V$. divergens showed little change in growth and gas exchange in response to experimental shading, but experimental flooding significantly reduced rates of physiological performance. However, $V$. divergens saplings exhibited positive growth and $\mathrm{C}$ gain in the flooded and shaded treatment, indicating that this species is tolerant to both flooding and shading. Such tolerance, and the physiological flexibility to gain $\mathrm{C}$ in a wide variety of hydrological and growth light conditions, presumably explains the ability of $V$. divergens to invade, and ultimately form dense, monospecific stands, in the Brazilian Pantanal.

Acknowledgements: The authors acknowledge the Graduate Program in Environmental Physics of Universidade Federal de Mato Grosso, for the equipment and laboratory support. Financial support was provided by Fundação de Amparo à Pesquisa do Estado de Mato Grosso (FAPEMAT) - project named "Análise do potencial fotossintético, da eficiência no uso de nitrogênio e da água da Vochysia divergens Pohl (Vochysiaceae), em um gradiente ambiental entre o Pantanal e o Cerrado"; National Counsel of Technological and Scientific Development (CNPq) - project named "Pesquisas Ecológicas de 
Longa Duração" (PELD). The authors would also like to acknowledge Instituto Nacional de Ciência e Tecnologia em Áreas Úmidas (INAU), Programa Institutos Nacionais de Ciência e Tecnologia - CNPq/MCT and Coordination for the improvement of Higher Education Personnel (CAPES), which provided scholarships to ACD, HJD and MZAJ.

\section{REFERENCES}

Arieira J, Nunes da Cunha C (2006) Fitossociologia de uma floresta inundável monodominante de Vochysia divergens Pohl (Vochysiaceae), no Pantanal Norte, MT, Brasil. Acta Bot. Bras. 20:569-580.

Armstrong W, Brandler R, Jackson MB (1994) Mechanisms of flood tolerenace in plants. Acta Bot. Neerl. 43:307-358.

Bossard C, Randall, Hoshovsky M (2000) Invasive Plants of California's Wetlands. University of California Press, California.

Bradford KJ (1983) Effect of soil flooding on leaf gas exchange of plants. Plant Physiol. 73:475-479.

Braga JM, Defelipo B (1974) Determinação espectrofotométrica de fósforo em extratos de solos e plantas. Revista Ceres 21:73-85.

Borges DLG, Curtius AJ, Welz B, Heitmann U (2005) Fundamentos da espectrometria de absorção atômica de alta resolução com fonte contínua. Rev. Anal. 18:58-66.

Clark LH, Harris WM (1981) Observation on the root anatomy of rice. Observations on the Root Anatomy of Rice (Oryza sativa L.). Am. J. Bot. 68:154-161.

Colmer TD, Greenway H (2010) Ion transport in seminal and adventitious roots of cereals during $\mathrm{O}_{2}$ deficiency. J. Exp. Bot. 9:1-19.

Crawford RMM (1992) Oxygen availability as an ecological limit to plant distribution. Adv. Ecol. Res. 23:93-185.

Dalmolin AC, Dalmagro HJ, Lobo FA, Antunes Junior MZ, Ortiz CER, Vourlitis G. The photosynthetic light and carbon dioxide response of the invasive tree, Vochysia divergens Pohl., to experimental flooding and shading. Photosynthetica (in press).

Damasceno-Junior GA, Semir J, Santos FAM, Leitão-Filho HF (2005) Structure, distribution of species and inundation in a riparian forest of Rio Paraguai, Pantanal, Brazil. Flora 200:119-135.

Drew MC (1997) Oxygen deficiency and root metabolism: injury and acclimation under hypoxia and anoxia. Annu. Rev. Plant Physiol. 48:223-250.

Fernández MD, Pieters A, Donoso C, Herrera A (1999) Seasonal changes in photosynthesis of trees in the flooded forest of Mapire river. Tree Physiol. 19:79-85.

Funk JL (2008) Differences in plasticity between invasive and native plants from a low resource environment. J. Ecol. 96:1162-1173.

Golterman HL, Clymo RS, Ohnstad MAM (1978) Methods for physical and chemical analysis of fresh water. Blackwell, Oxford.

Herrera A, Rengifo E, Tezara W (2010) Respuestas ecofisiológicas a la inundación en árboles tropicales tolerantes de un igapó. Ecossistemas. 19:37-51.

Holbrook NM, Shashidhar VR, James RA, Munns R (2002) Stomatal control in tomato with ABA-deficient roots: Response of grafted plants to soil drying. J. Exp. Bot. 53:1503-1514.
Holmes MG, Smith H (1977) The function of phytochrome in the natural environment-II. The influence of vegetation canopies on the spectral energy distribution of natural daylight. Photochem. Photobiol. 25:539-545.

Hunt PH, Campbell RB, Sojka RE, Parsons JE (1981) Flooding-induced soil and plant ethylene accumulation and water status response of fieldgrown tobacco. Plant Soil. 59:427-439.

Hunt R, Parsons IT (1974) A computer program for deriving growthfunctions in plant growth-analysis. J. Appl. Ecol. 11:297-307.

Isaac RA, Kerber JO (1971) Atomic absorption and flame photometry: technique and uses in soil, plant and water analysis. In: Walsh LM (eds), Instrumental methods of analysis of soils and plant tissue. Soil Science Society America, Madison.

Ishida FY, Carvalho CJR (2002) Respostas de pupunheiras (Bactris gasipaes Kunth) jovens ao alagamento. Pesq. Agrop. Bras. 37:1231-1237.

Ishida FY, Oliveira LEM, Carvalho CJR, Alves JD (2002) Efeitos da inundação parcial e total sobre o crescimento, teor de clorofila e fluorescência de Setaria anceps e Paspalum repens. Ciênc. Agrotec. 26:1152-1159.

Jackson MB, Colmer TD (2005) Response and adaptation by plants to flooding stress. Ann. Bot. 96:501-505.

Jacomino AP, Mendonça K, Kluge RA (2003) Armazenamento refrigerado de limões "siciliano" tratados com etileno. Rev. Bras. Frut. 25:45-48

Joly CA, Crawford RMM (1982) Variation in tolerance and metabolic responses to flooding in some tropical trees. J. Exp. Bot. 33:799-809.

Junk WJ, Nunes de Cunha C (2005) Pantanal: a large South American wetland at a crossroads. Ecol. Eng. 24:391-401.

Junk WJ, Nunes da Cunha C, Wantzen KM, Petermann P, Strussmann $\mathrm{C}$, Marques MI, et al. (2006) Biodiversity and its conservation in the Pantanal of Mato Grosso, Brazil. Aquat. Sci. 68:278-309.

Kozlowski TT (1997) Responses of woody plants to flooding and salinity. Tree Physiology Monograph, Victoria. 1:1-29.

Kozlowski TT, Pallardy SG (2002) Acclimation and adaptive responses of woody plants to environmental stresses. Bot. Rev. 68:270-334.

Lake JC, Leishman MR (2004) Invasion success of exotic plants in natural ecosystems: the role of disturbance, plant attributes and freedom from herbivores. Biol. Conserv. 117:215-226.

Larcher, W (1995) Physiological Plant Ecology. Springer-Verlag, New York

Lite SJ, Stromberg JC (2005) Surface water and ground-water thresholds for maintaining Populus-Salix forests, San Pedro River, Arizona. Biol. Conserv. 125:153-167.

Lorenzi H (1998) Árvores Brasileiras. Manual de Identificação e Cultivo de Plantas Arbóreas Nativas do Brasil. Editora Plantarum, Nova Odessa.

Maurenza D, Marenco RA, Piedade MTF (2009) Efeito da inundação de longa duração sob o crescimento de Pouteria glomerata (Sapotaceae), uma arbórea da várzea da Amazônia Central. Acta Amaz. 39:519-526.

McKee WH, McKevlin MR (1993) Geochemical processes and nutrient uptake by plants in hydric soils. Environ Toxicol Chem. 12:2197-2207.

Mielke MS, Almeida AF, Gomes FP, Aguilar MA, Mangabeira PA (2003) Leaf gas exchange, chlorophyll fluorescence and growth responses of Genipa americana seedlings to soil flooding. Environ. Exp. Bot. 50:221-231.

Miranda EJ, Vourlitis GL, Priante Filho N, Priante PC, Campelo Jr. JH, Suli GS, et al. (2005) Seasonal variation in the leaf gas exchange of tropical forest trees in the rain forest-savanna transition of the southern Amazon Basin. J. Trop Ecol. 21:451-460. 
Miyazawa M, Pavan MA, Muraoka T, do Carmo CAFS, De Melo WJ (2009) Análise química de tecido vegetal. In: Da Silva FC, Manual de análises químicas de solos, plantas e fertilizantes, $2^{a}$ ed. rev. ampl. Embrapa Informação Tecnologia, Brasília, DF.

Nunes da Cunha C, Junk WJ (2004) Year-to-year changes in water level drive the invasion of Vochysia divergens in Pantanal grasslands. App. Veg. Sci. 7:103-110.

Nunes da Cunha C, Junk WJ, Leitão Filho HF (2007) Floristic and physiognomic types of arboreal vegetation of the Pantanal of Poconé, Mato Grosso. Amazoniana 19:159-184.

Osunkoya 00, Bayliss D, Panetta D, Vivian-Smith G (2010) Variation in ecophysiology and carbon economy of invasive and native woody vines of riparian zones in south-eastern Queensland. Austral Ecol. 35:636-649.

Oliveira VC de, Joly CA (2010) Flooding tolerance of Calophyllum brasiliense Camb. (Clusiaceae): morphological, physiological and growth response. Trees 24:185-193.

Pezeshki SR, Pardue JH, DeLaune RD (1993) The influence of oxygen deficiency and redox podential on alcohol dehydrogenase activity, root porosity, ethylene production and photosynthesis in Spartina patens. Environ. Exp. Bot. 33:565-573.

Pott A, Pott VJ (1994) Plantas do Pantanal. Empresa Brasileira de Pesquisa Agropecuária, Centro de Pesquisa Agropecuária do Pantanal, Corumbá.

Rehem BC, Almeida AF, Mielke MS, Gomes FP (2009) Efeitos do alagamento do substrato no crescimento e na composição química de genótipos clonais de Theobroma cacao L. Rev. Bras. Frut. 31:805-815.

Rejmanek M, Richardson DM (1996) What Attributes Make Some Plant Species More Invasive? Ecology 77:1655-1661.

Sala A, Smith SD, Devitt DA (1996) Water use by Tamarix ramosissima and associate phreatophytes in a Mojave Desert floodplain. Ecol Appl. 6:888-898.

Shimamura S, Yamamoto R, Nakamura T, Shimada S, Komatsu S (2010) Stem hypertrophic lenticels and secondary aerenchyma enable oxygen transport to roots of soybean in flooded soil. Ann. Bot. 106:277-284.
Siemann E, Rogers WE (2007) The role of soil resources in an exotic tree invasion in Texas coastal prairie. J. Ecol. 95:689-697.

Silva MP, Mauro R, Mourão G, Coutinho M (2000) Distribuição e quantificação de classes de vegetação do Pantanal através de levantamento aéreo. Rev. Brasil. Botânica. 3:143-152.

Santos SA, Cunha CN, Tomás W, Abreu UGP, Arieira J (2006) Plantas Invasoras no Pantanal: Como Entender o Problema e Soluções de Manejo por Meio de Diagnóstico Participativo. Embrapa Pantanal Boletim de Pesquisa e Desenvolvimento 66 - Empresa Brasileira de Pesquisa Agropecuária: Centro de Pesquisa Agropecuária do Pantanal, Ministério da Agricultura, Pecuária e Abastecimento, Corumbá - MS, 45p.

Sena GAR, Kozlowski TT (1988) Physiological and growth responses to flooding of seedlings of Hevea brasiliensis. Biotropica 20:286-296

Tournaire-Roux C, Sutka M, Javot H, Gout E, Gerbeau P, Luu DT, et al. (2003) Cytosolic pH regulates root water transport during anoxic stress through gating of aquaporins. Nature 425:393-397.

Vourlitis GL, Lobo FA, Biudes MS, Ortíz CER, Nogueira JS (2011) Spatial variations in soil chemistry and organic matter content across a Vochysia divergens invasion front in the Brazilian Pantanal. Soil Sci. Soc. Am. J. 75:1554-1561.

Ward JP, Smith SE, McClaran MP (2006) Water requirements for emergence of Buffelgrass (Pennisetum ciliare). Weed Sci. $54: 720-725$

Wilkinson S, Davies WJ (2002) ABA-based chemical signaling: the co-ordination of responses to stress in plants. Plant Cell. Environ. $25: 195-210$.

Wong SC, Cowan IR, Farquhar GD (1979) Stomatal conductance correlates with photosynthetic capacity. Nature 282:424-426.

Zhang J, Toai T, van Huynh L, Preiszner J (2000) Development of flooding-tolerant Arabidopsis thaliana by autoregulated cytokinin production. Mol. Bred. 6:135-144. 